libido, and hypertension. The authors compare these symptoms with those encountered in hepatitis ${ }^{2}$ and in the first three months of pregnancy. ${ }^{3}$ They suggest that the cause may lie in a disturbance of trace metals ${ }^{4}$ and report that treatment with orally administered copper, zinc, or nickel has resulted in the return of taste to normal. 45

The patients ranged in age from 34 to 68 years, and half of them had a preceding infection of the upper respiratory tract. The authors used different dilutions of the salty, sweet, bitter, and sour solutions to test taste. As an objective measurement of smell they used pyridine in water and nitrobenzene and thiophene in mineral oil in various concentrations. Three case histories given show that the obnoxious taste and smell of food caused the patients to lose $10-30 \mathrm{lb}(4.5-13.6 \mathrm{~kg})$ in weight. The authors describe pathological changes in the pore region of a taste bud, where they found fewer neurosecretory granules than normal, larger vacuoles, and more highly vesiculated cells but loss of cytoplasmic projections. These histological changes lend support to the proposition that a disorder with a distinct pathology is the explanation of these unpleasant symptoms. Henkin and colleagues report that they know of at least 3,000 sufferers from this complaint, and they are engaged in a double-blind trial of zinc given by mouth to try and confirm their initial favourable results.

1 Henkin, R. I., Schechter, P. J., Hoye, R., and Mattern, C. F. T., Fournal of the American Medical Association, 1971, 217, 434 .

2 of the American Medical Association, 1971, 217, 434.

3 Kirsner, J. B., and Van Woert, M., in Obstetrics, ed. J. P. Greenhill, Kirsner, J. B., and Van Woert, M., in Obster
p. 536. Philadelphia, W. B. Saunders, 1960.

4 Henkin, R. I., Graziadei, P. P. G., and Bradley, D. F., Annals of Internal Medicine, 1969, 71, 791 .

5 Henkin, R. I., and Bradley, D. F., Life Sciences, 1970, 9, 701.

\section{Future of British Psychiatrists}

This year on 16 June a new royal college began its existence, under unique circumstances. For nearly a century and a half the Royal Medicopsychological Association (R.M.P.A.) had been in existence as a vigorous scientific and professional society to which most British psychiatrists belonged, no matter what their grade or place of work. Psychiatric hospitals are scattered across the British Isles, and the number of doctors working in them and in other newer psychiatric facilities makes psychiatry one of the biggest specialties in medicine. The R.M.P.A. had done pioneer work in providing courses of lectures and in holding examinations for a diploma long before there was a professor of psychiatry in any medical school, and its regional organization had brought psychiatrists together regularly for scientific and-social gatherings in different provincial hospitals. But in the field of training its efforts had not kept pace with a growing need. It was widely recognized that psychiatric knowledge and practice varied greatly from place to place, and that a considerable number of new psychiatrists were growing up more or less self-taught through lack of guidance and teaching.

For these reasons the leaders of the R.M.P.A., with the general approval of its membership, resolved to turn the association into a college, which would hold regular examinations for a membership and set a new higher standard of knowledge throughout British psychiatry, with improved training facilities. Of course, such a membership, and even more the Fellowship, would be valued only if some effort was needed to gain it and if its possession led to professional advancement. This plan posed two principal problems from the outset: firstly, how to fit the members of a society previously open to almost anyone on payment of a fee into the normal structure of a college; secondly, how to start holding a membership examination of high standard to select future members without being unfair to those who had had little access to training or who worked in some particular subspecialty.

Any solution to the first problem was bound to upset some R.M.P.A. members, who would then feel that they had been wrongly graded and deprived of their rights. The solution to the second problem had not merely to avoid being unfair to a particular group, but to avoid becoming a weapon with which the seniors could control the juniors, or denude the Health Service of consultantsresults which might destroy the new college's reputation instead of raising standards.

Mid-June is not an ideal time of year to begin a new royal college. There was a vast burden of administrative work to get through during the summer, firstly in deciding who the foundation members and Fellows, council, and president would be, so that the college could be called together, and secondly in setting the new examinations going without delay, to show junior psychiatrists in good time what would be expected of them, as well as to satisfy the charter. The Fellows were mostly consultant psychiatrists of twelve or more years' standing, the new members the younger consultants, and the court of electors was kept very busy examining the credentials of others and considering appeals from yet others for the grant of foundation membership. A wave of dismay began to spread, particularly among senior registrars, when appeals were rejected and it was seen that many would have to sit yet another examination, the new membership, whose entrance fee was $£ 60$.

This intensified when it was announced that the new examination could begin in November and February and cover a wide range of subjects. An Association of Psychiatrists in Training sprang into being, with the aim of protecting the interests of junior psychiatrists. Periods of rapid change are always times when anxieties mushroom. Suspicions and rumours began to increase and all seemed set for a big explosion of feeling.

Last week the new college met for the first time. It had a newly elected president in Professor Martin Roth of Newcastle upon Tyne and a newly elected council containing many new men, voted in by the foundation members and Fellows. The college proceeded to show that it was prepared to compromise, to evolve, and not to be bound by the decisions of the previous caretaker administration. The President announced that five independent Fellows would examine appeals from adverse decisions of the court of electors, and the assembled foundation members and Fellows voted to make themselves pay the examination fees for the membership examination they did not have to sit so that the applicants who did have to sit it would not feel at a financial disadvantage. At a special meeting on 19 November representatives of the Association of Psychiatrists in Training stated their objections to the new examinations, heard explanations of their nature and costing, and in a sympathetic atmosphere accepted in large measure the college's genuine willingness to review and revise its plans as it deveiops in the coming months. 
This acceptance was due above all to the evident sincerity, sensitiveness, and intellectual power with which the meeting was conducted. It now lies with the college's council and the bodies which derive from it to work hard to make good use of this breathing space. They will need to publish quickly a provisional list of the college members, Fellows, and functionaries; an explanatory syllabus for the membership examination; the plans to improve regional training and provide a special membership course; and what they intend to do about some of the more difficult problems in the regions.

The first five months of the royal college's existence were marred by a lack of understanding of legitimate anxieties, fed by insufficient information. Now that the college has met for the first time the way is open to a smooth development of the work it has set itself in raising the standards of British psychiatry. We wish the college well in its task.

\section{Amenorrhoea after the Pill}

Amenorrhoea occurring in patients after taking oral contraceptives was first reported in 1966.1 There is always some uncertainty about the relationship between them, for we know little of the incidence and causes of secondary amenorrhoea in the general population to compare it with the incidence in women who discontinue oral contraceptives. Many patients with amenorrhoea on stopping the pill have in addition galactorrhoea, and so far 41 wellauthenticated cases of this association have been reported.

Prolonged galactorrhoea with amenorrhoea can occur spontaneously after parturition, when it is called the ChiariFrommel syndrome. In women stopping oral contraceptives the syndrome would appear to be rare. In fact it is worth emphasizing that a return of ovulation can be expected within the first three cycles after stopping oral contraceptives in $98 \%$ of women. ${ }^{2}$ No specific compound has been identified as causing the syndrome; both combined and sequential oral contraceptives are known to do so. No patient appears to have developed amenorrhoea and galactorrhoea when contraceptives were taken for less than three cycles, ${ }^{3}$ but there is no obvious time relationship other than this. In one series ${ }^{4}$ the duration of contraception varied from six months to four years, with half the patients being on it for two years or less. None of the patients in the published series had an obvious endocrinological cause either of the amenorrhoea, such as pituitary tumour, or of the galactorrhoea, such as other drugs. It seems that women with pre-existing menstrual irregularities are more prone to the condition than normal women, and in the individual case it is prudent to consider whether other methods of contraception are preferable to the pill.

The cause of amenorrhoea and galactorrhoea, whether these are related to oral contraceptives or occur spontaneously, appears to be prolonged exposure of the hypothalamo-pituitary axis to progesterone and oestrogens. These may have either exogenous or endogenous sources.
D. R. Halbert and C. D. Christian ${ }^{3}$ found evidence of impaired pituitary function in four out of five patients whose response to hypoglycaemia was measured by the change in levels of growth hormone. Levels of serum follicle-stimulating hormone (FSH) and luteinizing hormone $(\mathrm{LH})$ were either normal or low in 10 patients $^{4}$ with the syndrome.

The prognosis of these patients is uncertain. E. RiceWray and her colleagues ${ }^{2}$ reported the resumption of menstruation spontaneously in eight patients with post-pill amenorrhoea lasting 3-13 months. If the patient does not present with the problem of infertility, the immediate solution is somewhat easier, as the administration of an oestrogen-progesterone compound for five days by mouth will usually induce a withdrawal bleed and thus eliminate some of the anxieties associated with the amenorrhoea. But this form of symptomatic treatment does not cause resumption of normal menses.

Most patients present with infertility, and the aim of treatment is to induce ovulation. The most successful methods are to use clomiphene, which stimulates pituitary secretion of gonadotrophin, and if this fails to follow it with a course of chorionic gonadotrophin. This treatment must be regulated by specialists and demands considerable co-operation from the patient. But even with this the eventual success rate as judged by a subsequent pregnancy is probably no greater than $50 \%$.

1 Shearman, R. P., Lancet, 1966, 2, 1110

Rice-Wray, E., Correu, S., Gorodovsky, J., Esquivel, J., and Goldzieher, J. W., Fertility and Sterility, 1967, 18, 212.

${ }^{3}$ Halbert, D. R., and Christian, C. D., Obstetrics and Gynecology, 1969, 34, 161 .

${ }^{4}$ Gambrell, R. D., Greenblatt, R. B., and Mahesh, V. B., American Fournal of Obstetrics and Gynecology, 1971, 110, 838.

\section{Scientific Basis of Clinical Practice}

Anyone who questions the value of the basic medical sciences for a practising clinician should compare the account of the aetiology of diabetes in a modern textbook and, say, Osler's textbook published in 1892. Explanation and understanding of the nature of a disease are greatly simplified by accurate knowledge of its causation. But despite the questions on medical science in some postgraduate examinations, this is one field on the whole still poorly served by our postgraduate centres. The Midlands have long been noted for the vigour and variety of their postgraduate activities, and two years ago decided to add to these a weekly series of lectures in the clinical sciences. As Dr. R. E. Smith pointed out last week, ${ }^{1}$ this course has already proved that it can establish important liaisons between the clinician and the teacher of basic sciences, as well as providing valuable training for the potential consultant or general practitioner. In the coming months the B.M.F. will be nublishing many of the lectures in this series. We hope they will be read by a wide variety of doctors with interest.

1 Smith, R. E., British Medical fournal, 1971, 4, 482. 